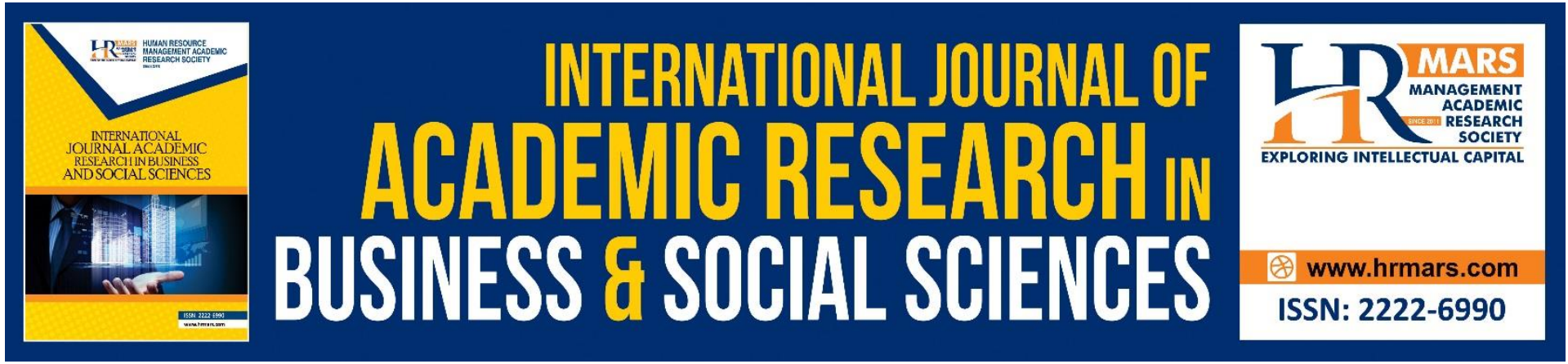

\title{
The Impact of Universiti Teknologi MARA (UiTM) Towards Local Entrepreneurial Development: The Case of Negeri Sembilan
}

Mumtaz Ahmad, Aini Hayati Musa, Farrah Nadia Baharuddin, Alia Nadira Rosle, Siti Sara Ibrahim, Norfadzilah Abdul Razak

To Link this Article: http://dx.doi.org/10.6007/IJARBSS/v11-i8/10825 DOI:10.6007/IJARBSS/v11-i8/10825

Received: 06 June 2021, Revised: 08 July 2021, Accepted: 29 July 2021

Published Online: 24 August 2021

In-Text Citation: (Ahmad et al., 2021)

To Cite this Article: Ahmad, M., Musa, A. H., Baharuddin, F. N., Rosle, A. N., Ibrahim, S. S., \& Razak, N. A. (2021). The Impact of Universiti Teknologi MARA (UiTM) Towards Local Entrepreneurial Development: The Case of Negeri Sembilan. International Journal of Academic Research in Business and Social Sciences, 11(8), 1169-1178.

Copyright: (c) 2021 The Author(s)

Published by Human Resource Management Academic Research Society (www.hrmars.com) This article is published under the Creative Commons Attribution (CC BY 4.0) license. Anyone may reproduce, distribute, translate and create derivative works of this article (for both commercial and non-commercial purposes), subject to full attribution to the original publication and authors. The full terms of this license may be seen at: http://creativecommons.org/licences/by/4.0/legalcode

Vol. 11, No. 8, 2021, Pg. 1169 - 1178

Full Terms \& Conditions of access and use can be found at http://hrmars.com/index.php/pages/detail/publication-ethics 


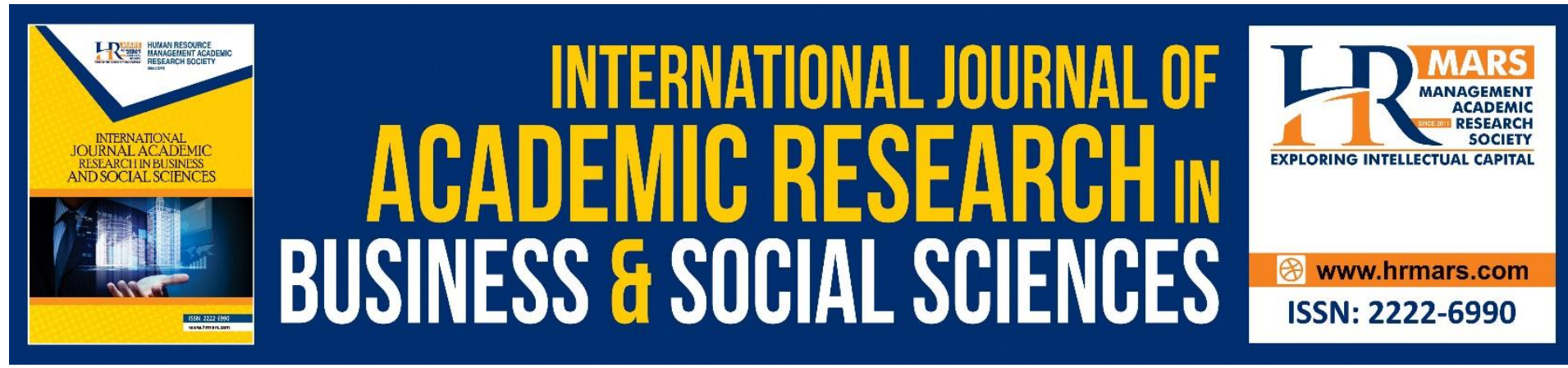

\title{
The Impact of Universiti Teknologi MARA (UiTM) Towards Local Entrepreneurial Development: The Case of Negeri Sembilan
}

\author{
${ }^{1}$ Mumtaz Ahmad, ${ }^{1}$ Aini Hayati Musa, ${ }^{1}$ Farrah Nadia Baharuddin, \\ ${ }^{2}$ Alia Nadira Rosle, ${ }^{1}$ Siti Sara Ibrahim, ${ }^{1}$ Norfadzilah Abdul \\ Razak \\ ${ }^{1}$ Faculty of Business and Management, Universiti Teknologi MARA (UiTM), Malaysia, \\ ${ }^{2}$ Faculty of Computer Science and Mathematics, Universiti Teknologi MARA (UiTM), \\ Malaysia.
}

\begin{abstract}
Universiti Teknologi MARA has branch campuses in almost every state in the country and Negeri Sembilan Darul Khusus was the last state selected for establishing more branch campuses. The establishment of the Universiti Teknologi MARA Negeri Sembilan Branch (UiTM CNS) in 2009 has provided major changes to local socio-economic growth. This paper aims to study the pattern of business economic activities around UiTM CNS and measure the level of economic impact contributed by UiTM CNS. The method use in this paper are land use categorization using geographical information system (GIS), and followed by a survey. Questionnaires were distributed by employing simple random sampling method. 63 respondents participated was the chief executive or the owner of industrial or business companies within a distance of $10 \mathrm{~km}$ radius from the UiTM campus. Data collected from the survey were analysed using cross-tabulation. It was found that, more than $90 \%$ of the business owners agreed that UiTM CNS is one contributor to their business growth. The findings further explained that the high numbers of students and staff in UiTM CNS are the customer's main target group for their business. 60 percent of the local business/ industry owners agreed that location is the main reason they choose to set up their business. The area near UiTM CNS is a strategic location that has a high number of customers. This also supported by result from land used observation which using using site data collection, satellite image interpretation and digital image processing. Analysis for land use categorization was done using geographical information system (GIS), geospatial web-based maps applications and the production of the map. From the map, the developed areas shows the increase of infrastructures inclusive road and highway. It is from the increases the population of people that stay within the area that indirectly contribute to the development area. Hence, the findings from the study can rationalize the development impact by UITM CNS and be a benchmark to strategize future plan.
\end{abstract}


Keywords: Higher Education Institutions, Socio-economic Growth, Sustainability, Local Entrepreneurial, Development

\section{Introduction}

The development of the branch of Universiti Teknologi MARA Negeri Sembilan Branch (UiTM CNS) has created institutional growth and provide opportunities for people in this country to gain knowledge in different major fields. The newly established campuses in the state are in line with institutional growth to open up a corridor for education hubs. The first UiTM Negeri Sembilan branch campus in the state is in Kuala Pilah followed by Seremban 3, while the third campuses located in Rembau. Apart from the small town of Kuala Pilah, Seremban 3 and Rembau town itself, the development area consists of 90 percent of conventional village areas, not really very quality suburban areas. Even though vigorous development has taken place but the identity, and the landscape of the state remains the same. The aim is to retain the identity of the village and at the same time improve certain areas without affecting the original landscape as customary land. The presence of growth in education offers an incentive for dramatic change in the sector. Therefore, the existence at the same time of many students and teaching staff creates different basic requirements, such as accommodation needs, books and stationery, transportation, etc.

UiTM Negeri Sembilan branch is located in the South of Malaysia. It has three campuses where the main campus is located at Kuala Pilah. The temporary campus started operating on June 1, 1999, by taking over the East Negeri Sembilan Agricultural Complex, Ministry of Agriculture in Jalan Melang, Kuala Pilah. The UiTM Negeri Sembilan Campus Kuala Pilah permanent campus construction project was on 160 acres in Mukim Parit Tinggi that was started on March 13, 2007. UiTM Kuala Pilah has become one of the factors that influence the development of the Seremban area. Within the 20 years, the land conversion into the developed area is also noticed as quite significant. The transformations of the land into developed areas can be seen along with the Kuala Pilah areas where UiTM Kuala Pilah is located. The land-use conversions are mainly due to human settlements and business areas.

In the year of 2011, UiTM Seremban campus was launched on January 19, 2011. UiTM Seremban campus has become one of the factors that influence development in the Seremban area. Within the 20-year time frame, the conversion of land into developed areas is also quite significant. The transformations of land into developed areas can be seen along the Seremban Road, where UiTM Seremban is located. The land-use conversions are mainly due to human settlements and business areas. Universiti Teknologi MARA Negeri Sembilan Branch, Rembau campus covering 32.4 hectares, was built on August 26, 2013, and fully completed on August 25,2016 . The Rembau campus was officially operational on February 1 , 2017, with a strength of almost 800 students and staff.

Meanwhile, this UiTM CNS is expected to accommodate up to 10,000 students as it hits its maturity stage. All facilities, including hostels, halls, labs, sports centres and others, are completed at the university. Only 50 percent of students are equipped with hostel facilities. This means that the demand for housing needs in surround area will be higher to provide student placement needs later. The development of the UiTM CNS would provide educational benefits and cause the robust economic development chain in this district. It is also expected 
to be capable of achieving the plan of the government to increase the population in the region.

However, further research is needed to obtain up-to-date data on the impact of the existence of UiTM CNS campus on the local economic growth within the last 20 years. Furthermore, the fact that there are only a small number of papers discussing the direct relationship between the presence of a university and its local economic performance necessitates such research to be conducted. Therefore, the objectives of this study are:

1. To identify the pattern of the economic activity around UiTM Negeri Sembilan among the industries and businesses.

2. To identify the level of economic impact contributed by UiTM Negeri Sembilan on the development of the industries and business communities.

\section{Literature Review}

\section{Potential Environmental Effects}

In Malaysia, development policies that emphasize the industrial and municipal sectors the rapidity experienced has given some implications to the environmental health of the country especially in areas that have been developed. This is because the development project is aimed at encouraging economic growth is largely implemented regardless environmental problems that may arise. Thus, nowadays the deterioration of environmental quality can be said to occur anywhere in Malaysia especially in urban and even rural areas (Jahi, 1996).

The environmental problems experienced have increased as a result the impact of the implementation of unsustainable development. Therefore, it is not surprising why the impact development on the environment is currently increasing, although there are various the body responsible for overseeing it and increasing the rules and lines guidelines formulated to control it (Jahi, 1996).

In planning a development project, the ability of something the environment for recovery should be taken into account so that development activities do not destroying the natural system. Therefore, project suitability, site selection, planning, implementation, construction methods and technologies need to be planned especially in a dynamic environment recovering is very low so that the natural system is not disturbed (Said, 1999).

Development is a positive thing if carefully planned and take into account all the impacts on society and the environment but can have a negative impact if the development process takes place rapidly without control. There are several direct effects and problems that arise as a result of development, especially in urban areas, among them are as follows; Concentrated and uncontrolled development, Migration of rural people, poverty, provision of basic facilities, isolation of housing by race and economic status, social problems, pollution of physical environment (Jamaluddin, 2003).The urbanization that has occurred will inevitably lead to various positive and negative impacts on the socio-economic population of the suburbs (Samad et al., 2013).

Shirkanloo (2013) states that every urbanization process carried out should emphasize the economic, social and cultural aspects of the local people without giving significant changes to them. Salleh et al (2012) explained that most of the urbanization processes that have taken place now have led to the existence of various negative effects such as high land use, high 
energy production and water problems. Due to these inherent effects in urban areas, many residents have migrated to suburban areas to get a more perfect quality of life.

Salleh et al (2012) explained that as a result of the existence of development, there have been new economic opportunities for the community to participate in the development process involved.

\section{Methodology}

Study design plays a vital role in obtaining data or information. The satellite data is acquired from the satellite and sensors to study the land use land cover area. Another part of this study using quantitative data collected through questionnaires. The quantitative approach, example survey methods using questionnaires to collect adequate information, is used in this analysis. It is more realistic to use the method of administering the questionnaire to boost the precision and truthfulness of the respondents ' answers. Emphasis is provided to nearby UiTM Negeri Sembilan traders such as Kuala Pilah, Seremban 3 and Rembau,. In this study, respondents must run their business 50 meters within UiTM A Malaysian citizen must be the respondent.

\section{Sampling Method and Size}

In general, this study uses a random sampling method (convenience sampling). The questionnaires are distributed to 63 local businesses who agree to answer the questions given. The questionnaire is submitted to the Chief Executive of an industrial / business company taken according to the specific environmental distance in a district. This information will be collected along with other industries / businesses. The respondent was not identified as the industry / business individually.

\section{Study Instrument}

Two parts of questionnaires have been prepared for local businesses respectively. The questionnaire provided has been prepared in Malay. Part A contains the information of the respondents and Part $B$ contains 18 items with respect to the impact of Value 3 urbanization on local traders. The questionnaire is dedicated to the industries / businesses around UiTM CNS area for the purpose of identifying the economic impact of the use of UITM CNS existence on the industry.

\section{Research Scope}

This study has been set to local business located 10 meters within the area from UiTM CNS Kuala Pilah campus, Seremban 3 campus and Rembau campus respectively. This area has a strategic position and is close to UiTM CNS itself and there are various business activities carried out in the area. There are 63 respondents were randomly chosen. The respondent must be the local business within an area of 50 meters from UiTM CNS. The research was designed to be performed approximately 10 metres from the UiTM CNS area in order to fulfil the research objectives in order to evaluate the impact of UiTM CNS development on the local socio-economy.

\section{Findings and Discussion Demographic Factors}

This study was conducted to 63 of local business/ industry owner s in three districts of Negeri Sembilan which were 21 of the local business/ industry owner from Kuala Pilah (33.3\%), 21 
from Rembau (33.3\%), and 21 of local business/ industry owner from Seremban (33.3\%). As shown in Table 1, most of the companies that participated in this study were from a local company with a total of $61(96.8 \%)$ and only two companies from multinational. Thus this finding was dominantly by the local companies. Also, the sectors that involved were services which total of $43(68.3 \%), 4$ of them were from manufacturing (4\%) and only one from construction (1.6\%). Furthermore, 45 of the companies in this study registered as Bumiputra (71.5\%), and 18 were non-Bumiputra (287.5\%). There were also 42 of them have individual company $(67,74 \%), 6$ of them were partnership (9.68\%), 2 of them were Public Company Berhad (3.23\%), and 5 of them were Private Limited company (8.06\%).

Table 1: Demographic Factors

\begin{tabular}{|l|c|c|}
\hline \multicolumn{1}{|c|}{ Demographic Factors } & Frequency $(\mathrm{n})$ & Percentage (\%) \\
\hline Location of industry & 21 & 33.3 \\
Kuala Pilah & 21 & 33.3 \\
Rembau & 21 & 33.3 \\
Seremban & & \\
\hline Types of Company & 2 & 3.2 \\
Multinational & 61 & 96.8 \\
Local Company & & \\
\hline Sectors & 1 & 1.6 \\
Construction & 4 & 6.3 \\
Manufacturing & 43 & 68.3 \\
Services & 15 & 23.8 \\
Others & & \\
\hline Status Bumiputra & 18 & 28.5 \\
Non Bumiputra & 45 & 71.5 \\
Bumiputera & & \\
\hline Types of Company Registered & 42 & 67.74 \\
Individual & 6 & 3.68 \\
Partnership & 2 & 8.06 \\
Public Company Berhad & 5 & \\
Private Limited company & & \\
\hline
\end{tabular}

\section{Business Background}

In this study, 35 of the business have started the company from 2010 until the present $(55.6 \%)$ and followed by 14 operated companies from 2000 to 2010 (22.2\%), and only 12 of the business operated from 1970 to 1999 (19\%). Meanwhile, most companies conducted restaurants and food (41.27\%), 16 of the business are grocery (7.94\%), and 25.40 percent operated the services such as barber, printing, and $25.4 \%$. Next is the number of employees in the business. A majority of the local company has less than five employees $(41.27 \%)$, followed by 6 to 10 employees who were 22.2 percent. Furthermore, only five businesses have 11 to 20 employees, and 4 have more than 20 employees. Commonly there were from the manufacturing industry that operates the company near the location. 
Table 2. Years of Business Operation

\begin{tabular}{|l|c|c|}
\hline \multicolumn{1}{|c|}{ Years } & Frequency $(\mathrm{n})$ & Percentage (\%) \\
\hline $1970-1999$ & 12 & 19 \\
\hline $2000-2010$ & 14 & 22.2 \\
\hline $2010-2020$ & 35 & 55.6 \\
\hline
\end{tabular}

Table 3. Types of Products

\begin{tabular}{|l|c|c|}
\hline \multicolumn{1}{|c|}{ Types of Product } & Frequency $(\mathrm{n})$ & Percentage (\%) \\
\hline Restaurant and Food & 26 & 41.27 \\
\hline Grocery & 5 & 7.94 \\
\hline Services & 16 & 25.40 \\
\hline Others & 16 & 25.40 \\
\hline
\end{tabular}

Table 4. Numbers of Employees

\begin{tabular}{|l|c|c|}
\hline \multicolumn{1}{|c|}{ No of Employees } & Frequency $(\mathrm{n})$ & Percentage (\%) \\
\hline 1 to 5 & 39 & 61.90476 \\
\hline 6 to 10 & 12 & 22.2 \\
\hline 11 to 20 & 5 & 7.9 \\
\hline More than 21 & 4 & 6.3 \\
\hline
\end{tabular}

Factors that influence local business/ industry owner to operate business in Negeri Sembilan

There were many reasons for the local business/ industry owner chooses the location to start the business. As shown in Table 5, 60 percent of the local business/ industry owner $s$ gave reasons and claimed the area is the main reason why they choose to set up their business in the location. One of the sites is near the UiTM itself. The area near UiTM is a strategic location that has a high number of customers. Fifteen percent of them agreed due to the facilities surrounding the place, the residence, school, and shop lot. More finding highlights 15 percent of the business decision as no business provides such as stationery, printing, and salon. They believed that no company started yet at the location; there is a high opportunity to expand their business and attract more customers to fulfil their demand.

Table 5. Reason to Set the Business

\begin{tabular}{|l|c|c|}
\hline \multicolumn{1}{|c|}{ Reason } & Frequency $(\mathrm{n})$ & Percentage (\%) \\
\hline Location & 37 & 60.00 \\
\hline Facilities & 9 & 15.33 \\
\hline Demand & 17 & 26.98 \\
\hline
\end{tabular}

\section{Business and Alumni}

As shown in Table 6, there were 59 of respondents which is not alumni from UiTM $(95.23 \%)$, and only 3 of them were alumni which from UiTM Rembau and UiTM Kuala Pilah (4.77\%) 
Table 6: Business and Alumni

\begin{tabular}{|l|c|c|}
\hline \multicolumn{1}{|c|}{ Response } & Frequency $(\mathrm{n})$ & Percentage (\%) \\
\hline No & 60 & 95.23 \\
\hline Yes & 3 & 4.77 \\
UiTM Rembau & 2 & \\
UiTM Kuala Pilah & 1 & \\
\hline
\end{tabular}

\section{Business and UiTM Development}

As shown in Table 7, a question aimed to understand local local business/ industry owner s' perceptions of UiTM's existence as their surroundings. One of the questions was, "does UiTM development has an impact on the growth of the local business. Almost 90.5 percent of 57 local local business/ industry owner s agreed that UiTM is one contributor to their business growth. The findings further explained that the high numbers of students and staff in UiTM are the customer's main target group for their business. In detail, most of the local local business/ industry owner s claimed that 29 of them perceived there would be a minimal impact (46.5\%), 20 of them perceive moderate effects (31.7\%), and only 9 of them perceived as high impact $(14.3 \%)$ on UiTM development.

Table 7: Business and Alumni

\begin{tabular}{|l|c|c|}
\hline \multicolumn{1}{|c|}{ Response } & Frequency $(\mathrm{n})$ & Percentage (\%) \\
\hline Yes & 57 & 90.5 \\
Minimal Impact & 29 & 46.5 \\
Moderate Impact & 20 & 31.7 \\
High Impact & 9 & 14.3 \\
\hline No & 4 & 6.3 \\
No impact & 3 & 4.8 \\
\hline
\end{tabular}

Recommendation from local business/ industry owner to UiTM to assist the local business In this study, Table 8 shows the recommendation from the local company to UiTM to help them. Most of the local business/ industry owner recommend UiTM to organize the local business/ industry owner ship program for local business. The program such as business management, marketing, and digital local business/ industry owner ship. Also, they also suggest having technical skill training and program such as automotive and construction. 
Table 8. Recommendation

\begin{tabular}{|c|c|c|}
\hline List of Recommendation & Frequency (n) & Percentage (\%) \\
\hline $\begin{array}{l}\text { Local business/ industry owner } \\
\text { ship Program } \\
\text {-Marketing } \\
\text { - Local business/ industry } \\
\text { owner ship } \\
\text {-Computer and IT } \\
\text { - Social Marketing } \\
\text {-Food management } \\
\text {-Graphic Design }\end{array}$ & 40 & 65.00 \\
\hline $\begin{array}{l}\text { Technical Skill Training } \\
\text {-Repair Motorcycle } \\
\text { - Automotive } \\
\text {-Construction }\end{array}$ & 19 & 30.33 \\
\hline Others & 4 & 5.46 \\
\hline
\end{tabular}

\section{Conclusion}

From the study, the entrepreneurs agree the development UiTM is simultaneously giving major impact to their business. Even the students will not have all time in the area, but the facilities and amenities provided for the student's convenience indirectly will beneficial to the community nearby. Apart from that, UiTM CNS also undertake the consulting services and expertise to the government and the private sector, as well as Non Profit Organization. In addition, social responsibility activities has also become an organizational culture at work with the organization or community service programs consistently, especially to the benefits of local community in Negeri Sembilan.

\section{Acknowledgement}

We would like to thank Universiti Teknologi MARA (UiTM) for granting Bestari Research Grant (600-RMC/DANA 5/3/BESTARI (TD) (003/2019)) on Kajian Impak 20 Tahun UiTM and The Landsat data was available from the U.S. Geological Survey (USGS).

\section{Corresponding Author}

Mumtaz Ahmad

Senior Lecturer Faculty of Business and Management, Universiti Teknologi MARA, Negeri

Sembilan Branch, 72000 Kuala Pilah, Negeri Sembilan, MALAYSIA.

Email: mumtaz2627@uitm.edu.my

\section{References}

Bantanur, S., Mukherjee, M., \& Shankar, R. (2015). Emerging dimensions of sustainability in Institutes of higher education in India. International Journal of Sustainable Built Environment, 4(2), 323-329. doi:10.1016/j.ijsbe.2015.03.004

Boks, C., \& Diehl, J. C. (2006). Integration of sustainability in regular courses: Experiences in industrial design engineering. Journal of Cleaner Production, 14(9-11), 932-939. doi:10.1016/j.jclepro.2005.11.038 
Filho, W. L., Brandli, L., Castro, P., \& Newman, J. (2018). Handbook of theory and practice of sustainable development in higher education volume 1. Cham: Springer International Publishing.

Jamaluddin, Z. (2003). Implikasi proses pembandaran di Malaysia, in Asas Kefahaman Pengurusan Pembangunan. Sintok: Universiti Utara Malaysia.

Lozano, R., Lozano, F. J., Mulder, K., Huisingh, D., \& Waas, T. (2013). Advancing higher education for sustainable development: International insights and critical reflections. Journal of Cleaner Production, 48, 3-9. doi:10.1016/j.jclepro.2013.03.034

Jahi, M. J. (1996). Impak Pembangunan Terhadap Alam Sekitar. Bangi: Universiti Kebangsaan Malaysia.

Balan, N. P., \& Jusoh, H. (2020). Pembangunan Nilai 3 sebagai Bandar Usahawan dan Impaknya kepada Peniaga Tempatan dan Pengunjung. Jurnal Wacana Sarjana, 4(2), 18. Retrieved from http://spaj.ukm.my/jws/index.php/jws/article/view/267

Saleh, Y., Hashim, M., Nayan, N., \& Che Ngah, M. S. (2015). Peranan Universiti dalam Pembangunan Wilayah: Beberapa Bukti di Daerah Batang Padang, Perak. Perspektif: Jurnal Sains Sosial Dan Kemanusiaan, 7(1), 50 - 56. Retrieved from https://ejournal.upsi.edu.my/index.php/PERS/article/view/1697

Salleh, M., Badarulzaman, N., \& Salleh, A.G. (2012). Pembandaran dan Tren Perubahan Guna Tanah Di Luar Bandar:Kajian Kes Parit Raja, Batu Pahat Johor. Prosiding Seminar Serantau Ke-2 Pengurusan Persekitaran di Alam Melayu.

Said, M. A. (1999). Pengurusan Sumber Dan Alam Sekitar. Shah Alam: Institut Teknologi MARA.

Samad, S., Hanim, N., \& Shukor, S. (2013). Impak Pembangunan Industri Perlancongan Kepada Komuniti di Pulau Langkawi. Prosiding PERKEM VIII,Volume: JILID 1.

SDSN Australia/Pacific. (2017). Getting Started with the SDGs in Universities: A Guide for Universities, Higher Education Institutions, and the Academic Sector. Australia, New Zealand and Pacific Edition. Sustainable Development Solutions Network Australia/Pacific, Melbourne.

http://ap-unsdsn.org/wp-content/uploads/2017/08/University-SDG-Guide_web.pdf

Shirkanloo, N. (2013). Analyzing the Effects of Urban Sprawl on the Physical Environment in the Kyrenia. Eastern Mediterranean University of Cyprus.

Silva, J., \& Santos, S. (2004). Using input-output analysis to estimate the regional economic impact of universities: A case study. Retrieved December 15, 2007, from http://www.ecomod.org/files/papers/1342.pdf.

Tori, C., Steele, R., \& Steele, L. (2006). Valdosta State University economic impact study. Retrieved December 15, 2007, from http://www.valdosta.edu/news/releases/economic_impact_011005/.

Viebahn, P. (2002). An environmental management model for universities: from environmental guidelines to staff involvement. J. Clean. Prod., 10, pp. 3-12.

Wemmenhove, R., \& De Groot, W. T. (2001). Principles for university curriculum greening an empirical case study from Tanzania. International Journal of Sustainability in Higher Education, 2(3), 267-283. doi:10.1108/14676370110388354

Ziona, A. (2002). Cleveland State University: An Economic Impact Study. Urban Publications. 0123 263. https://engagedscholarship.csuohio.edu/urban_facpub/263 